\title{
Student Worksheet Based on Contextual Teaching and Learning in Linear Equation System Materials of Two Variables
}

\author{
$1^{\text {st }}$ Arnilawati \\ Department of Mathematics \\ Universitas Negeri Padang \\ Padang, Indonesia \\ arnilawati1812@gmail.com
}

\author{
$2^{\text {nd }}$ Armiati \\ Department of Mathematics \\ Universitas Negeri Padang \\ Padang, Indonesia
}

\author{
$3^{\text {rd }}$ Edwin Musdi \\ Department of Mathematics \\ Universitas Negeri Padang \\ Padang, Indonesia
}

\begin{abstract}
This research was derived from the low ability of students' problem solving. One of the factors was the students didn't understand the problem of mathematics related to real life and the development of learning media like students' worksheet had not been optimal yet in school. From that case, one of the efforts done was by using students' worksheet based on Contextual Teaching and Learning (CTL). The purpose of this research is to describe the characteristics of mathematical worksheet based on CTL to improve the problem solving ability of students on the Two Variable Linear Equation System (SPLDV) context in junior high school that fulfills the criteria of valid valid, practical and effective. This research used plomp development model. The plomp model consists of three phases, namely preliminary research, prototyping and assessment phase. Based on the development has been conducted, acquired Mathematics Students' Worksheet based on CTL on the SPLDV context in junior high school valid, practical and effective.
\end{abstract}

Keywords-Contextual, Problem Solving, Students' Worksheet

\section{INTRODUCTION}

Mathematics is the science that underlies the universal development of modern technology. He has a significant role in various disciplines and advances the power of human thought. To master technology and create a future, one needs mastery in mathematics at the beginning of school [1]. This is one of the factors underlying mathematics taught at all levels of education. The specific purpose of learning mathematics for students is that students have knowledge as a stock for higher levels of education. So that the goal of learning mathematics in schools can be achieved various efforts are made [2]. One of them is conveying information by linking material in daily life. As with the BNSP quote (2006) which mentions mathematics learning should begin with the introduction of problems that are appropriate to the real-life situation (contextual problem). Because, by asking contextual problems, students are gradually guided to master mathematical concepts.

Teachers as facilitators can help so that the learning process of students goes well, namely by training the students' independence in learning. But the reality in the field, learning activities are still focused on the teacher so that the involvement of students in the learning process is still minimal. In order for the role and task of the teacher as the facilitator to be achieved, the teacher can create learning media that can support the teaching and learning process.
One of the learning media that can be used is student's worksheet.

Student's worksheet is not an abbreviation of student activity sheets, but the student worksheets are teaching materials that have been packaged in such a way that students are expected to be able to study the teaching material independently [4]. Based on the results of these opinions, the student's worksheet can be used as a guideline so that students can actively engage in learning and help direct learners to construct knowledge so that students can find concepts. From the results of interviews with mathematics teachers, it is known that these problems occur because of the limitations of teachers to make and meet the needs of students in the process of learning mathematics. Students' worksheet that is designed has not met the needs of students to actively involve students in learning, both individually and in groups. The material contained in the student's worksheet designed by the teacher has not been presented contextually in building students' knowledge, motivation, and giving students the opportunity to find mathematical concepts. In addition, based on the results of interviews also obtained information that students are still not familiar with problem-solving problems and generally they are less able to write down the solution.

This problem-solving ability needs to be mastered by students to encourage them to become good problem solvers, who are able to deal with problems in everyday life and in the world of work. The reality shows, most of our lives are dealing with problems. Teaching problem solving to students allows students to become more analytical in making decisions in their lives [5]. Problem-solving ability in mathematics learning can be seen as a goal that must be achieved [6]. Problem-solving ability is an ability that is currently the main focus in learning mathematics in many countries [7].

Important awareness of problem-solving skills is also seen in Indonesia, where since the 2004 curriculum (KBK) Indonesia has included problem-solving abilities as one of the goals in mathematics learning. In the 2013 curriculum, problem-solving skills are also one of the abilities that students must possess. The 2013 curriculum adheres to the basic view that knowledge cannot be transferred from teacher to student. Students are subjects who have the ability to actively seek, process, construct and use knowledge [8]. But high abilities such as problem-solving are far from what 
is expected in the 2013 curriculum. This is because students are not used to working on problems in the form of problemsolving. One of the materials that require students to have problem-solving abilities is the Two-Variable Linear Equation System (SPLDV). This is in line with Rahayu's opinion which states that one of the materials that must be studied by junior high school students is SPLDV [9]. In everyday life, many calculation problems can be solved by implementing SPLDV, including money, business, age, and so on [10]. SPLDV questions are usually in the form of contextual stories, in order to solve these problems, it is necessary to stage a mathematical model or represent, then the problem can be solved later. Based on observations the researchers also obtained information that one of the materials that were considered difficult by students was the material of the Two-Variable Linear Equation System (SPLDV). In line with [11] the difficulty that is commonly felt by students on SPLDV material is that students find it difficult to find the concept of counting from SPLDV so that if the form of questions changes students cannot solve the given questions. This causes learning outcomes to be obtained by student's decreases.

Contextual Teaching and Learning (CTL) is a learning approach that makes daily use of life a problem or problem surrounding students as their learning object [12]. Contextual problems, or commonly called problems in the real world, are defined as problems that describe real-world situations according to student experience [13], where to solve them, students must be able to interpret problems, symbolize, manipulate, and solve problems by applying mathematical procedures or operations [14]. This also underlies the researchers choosing the development of CTL-based student's worksheet on SPLDV material. CTL-based student's worksheet preparation is very possible to direct students to solve mathematical problems in order to improve students' mathematical problem-solving skills. That ability will equip students to make connections between the knowledge they already have and new information that is applied in the context of everyday life. student's worksheet that is good in learning mathematics will provide the widest possible opportunity for students to develop their creativity in solving a problem.

\section{METHODS}

The development model applied is the Plomp model which consists of three phases; preliminary research, prototyping phase and assessment phase. This article only discusses the prototyping stage, namely on student's worksheet validation. In the preliminary study needs analysis, curriculum analysis, concept analysis and analysis of students were carried out. Data collection techniques through observation, interviews with mathematics teachers, questionnaires and initial tests with students of class VIII MTsN 6 Padang.

The prototype-making phase is done by designing a CTL based student's worksheet. The student's worksheet was developed based on Tessmer's formative evaluation. This evaluation consists of self-evaluation, expert validation, individual evaluation, small group evaluation and field testing. student's worksheet that has been developed is validated by 5 experts referred to as validators consisting of 3 mathematics education experts, one education technology expert and one Indonesian language expert. The validator will provide an assessment and suggestions on the design of the learning device in determining weaknesses and strengths, and by taking into account the expected product specifications using a validation sheet.

Data analysis techniques used in this study were analyzed descriptively. In the preliminary research data collection instruments in the form of needs analysis, curriculum, students and concepts, observation sheets and interview guidelines. Validity analysis is performed on the data obtained from the validity instrument results. Validation instruments include self-evaluation instruments and validation instruments.

\section{RESUlT AND DISCUSSION}

\section{A. Preliminary Research}

In the preliminary study needs analysis, curriculum analysis, concept analysis and analysis of students were carried out. Needs analysis is done to get information about the problems found in school learning both those faced by teachers and students. Information gathering is carried out by conducting interviews with teachers, observing the implementation of learning, and questionnaires of students. Whereas to see the ability of students to do the initial test. Preliminary tests carried out on students' problem-solving abilities with instruments in the form of questions that are adjusted to indicators of problem-solving abilities.

Curriculum analysis aims to analyze the curriculum on two supporting aspects namely KI and KD. At this stage, a review of the 2013 curriculum for junior high school mathematics classes in the eighth grade was carried out. The 2013 curriculum analysis was obtained from the VIII grade of SMP / MTs mathematics lesson syllabus in semester I. There were no changes to the established $\mathrm{KD}$, but on the achievement indicators, there was a change in the formulation of the SPLDV material. So, the CTL-based student's worksheet -assisted learning process is carried out in groups.

Concept analysis is the identification of the material to be discussed in learning. Discussion of the SPLDV material began with a simpler to the complex concept. The main concepts in the SPLDV material are (1) PLDV, (2) Completing the PLDV, (3) differentiating PLDV and SPLDV, (4) determining the completion of SPLDV, (5) resolving SPLDV by elimination and substitution methods, and (6) resolving SPLDV with combined method. The taught material is arranged systematically in accordance with the basic competencies in the syllabus.

Analysis of students is carried out to examine the characteristics of students in the eighth grade of junior high school. This analysis is used as a consideration in designing CTL-based student's worksheet which includes the way students learn, the participation of students, the importance of student's worksheet for students, and the description of student's worksheet that students like. So that the student's worksheet produced is in accordance with the characteristics possessed. In this study, students who will be used as subjects are students of grade VIII SMP. The questionnaire results of students showed that the character of students preferred learning activities together, students liked to discuss, learn by doing exercises and speaking in front of the 
class. Students' preference for color is based on color psychology. Previous study showed that favored color by humans is blue. This is in line with the results of the student questionnaire which shows that students prefer blue and bright colors. So blue and bright colors are chosen as the dominant color for CTL-based student's worksheet.

\section{B. Prototype Making}

The prototype-making phase begins with designing a CTL-based student's worksheet. This design is called prototype 1. The design of this student's worksheet is based on the results of preliminary research that has been carried out. After the CTL-based student's worksheet is produced, self-evaluation is carried out by the researcher himself for construct validity and discuss with experts for content validity. Validation of CTL-based student's worksheet contents was carried out by 5 experts consisting of 3 Mathematics Education experts, 1 Language expert and 1 Educational Technology expert.

The validity of the content means the suitability of the product produced with several criteria that are determined, conformity with the applicable curriculum content, suitability of the learning device with the syllabus, and the suitability of the device with the learning objectives. While construct validity means conformity between products produced with the elements of development that have been determined. The construct validity of the CTL-based student's worksheet is obtained through the preparation of devices based on the characteristics of the subject that is the target or the expected behavior of the subject.

In self-evaluation errors that researchers found in student's worksheet include typing errors and punctuation errors. After self-evaluation, the CTL-based student's worksheet was validated by the validator. After the improvements are made, the validators provide an assessment of student's worksheet. Overall CTL-based student's worksheet validated by mathematical experts have fulfilled valid criteria with a validity index of 0.85 , this means that the characteristics and suitability of student's worksheet with CTL-based learning can help students to improve their mathematical problem-solving abilities. The aspect that is seen next is the graphics aspect or appearance. The graphics aspect or display is validated by one lecturer in Education Technology. Analysis of the data of the graphics aspect validation results or the display obtained on average is 0.67 with a valid category, thus the graphics aspect or appearance is valid. The last aspect that is validated is the aspect of language. This language aspect is validated by one Indonesian lecturer. Data analysis of the results of language aspect validation obtained a validity index of 0.81 with valid criteria, this means that the language used in student's worksheet is communicative and valid. The overall validation results in each aspect can be seen in Table 1.

TABLE I. OVERALL STUDENT'S WORKSHEET VALIDATION RESULTS

\begin{tabular}{|c|c|c|}
\hline No & Aspect assessed & Validity Index \\
\hline 1. & Presentation & 0,84 \\
\hline 2. & Feasibility of contents & 0,86 \\
\hline 3. & Integrate or display & 0,67 \\
\hline 4. & Loyalty & 0,81 \\
\hline \multicolumn{2}{|c|}{ Average Validity Index } & 0,79 \\
\hline \multicolumn{2}{|c|}{ Criteria } & Valid \\
\hline
\end{tabular}

Based on Table 1 it can be seen that the average student's worksheet validation as a whole is 0.79 with valid criteria. So, it can be concluded that student's worksheet with CTL-based learning is valid.

\section{Assessment Phase}

The assessment phase is carried out at the field test stage. The field test phase is carried out to see the practicality and effectiveness of student's worksheet. Field testing is carried out for students in a class, namely, class VIII-12 MTsN 6 Padang as many as 36 students. Students are divided into 8 groups, each group consists of 4-5 students. Field tests were carried out in 6 meetings. During the field test, the researcher was assisted by one teacher and one observer.

Mathematics teachers teach using student's worksheet that researchers have designed. Before the teacher teaches the large group the researchers first do one-to-one and discuss with the teacher. Researchers provide tools that researchers make for student's worksheet. This is so that the teacher can first understand the steps of CTL-based learning activities. In addition, researchers also provide student's worksheet answer keys as a teacher's guide to teaching. For an evaluation of the CTL-based learning steps for large groups, researchers also held discussions with the teacher after class hours were over. This is so that the teacher can carry out CTL-based learning well.

Schedule of learning implementation in the field test phase in accordance with the usual learning schedule. Mathematics learning schedule for class VIII-12 MTsN 6 Padang on Wednesday and Saturday. At the time of learning, each student used CTL-based student's worksheet to learn SPLDV material, while researchers and observers observed the learning process using an implementation observation sheet. After learning is carried out using student's worksheet until the sixth meeting, students complete the practicality questionnaire. The practicality questionnaire is filled by the teacher aimed at getting information about the practicality of student's worksheet based on the teacher's consideration. Based on the results of the practicality questionnaire filled in by students, the average practicality value is $80.9 \%$ in very practical criteria. So it can be concluded that student's worksheet with CTL approach can be used well by students in learning.

The effectiveness of the use of CTL-based student's worksheet is seen from the value of the final test to see the students' problem-solving abilities after all meetings have been completed. Final test questions are adjusted to indicators of achievement of competence in SPLDV material. The test results of 36 students at this stage are 28 people with a percentage of $77.78 \%$ said to be complete, meaning that students have obtained the same value or exceed the KKM (75). CTL-based student's worksheet is said to be effective if more than $75 \%$ of students get the same value or exceed the KKM. So it can be concluded that CTL-based student's worksheet that has been developed has been effective to improve students' mathematical problemsolving abilities. 


\section{CONCLUSION}

Based on the results of the validation, information was obtained that this development and design had produced CTL based student's worksheet to improve students' problem-solving skills in junior high schools that meet the criteria of valid, practical and effective.

\section{REFERENCES}

[1] Djadir. Upu. Sulfianti, "The Profile of Students' Mathematical Problem Solving on the Topic of Two-Variable Linear Equation Systems Based on Thinking Styles", International Conference on Statistics. Mathematics. Teaching and Research, 1028(2018) 012164, 2018.

[2] Ekowati. Krisnandari, "The Application of Contextual Approach in Learning Mathematics to Improve Students Motivation At SMPN 1 Kupang", International Education Studies; Vol. 8, No. 8; 2015 ISSN 1913-9020 E-ISSN 1913-9039 Published by Canadian Center of Science and Education.

[3] Badan Standar Nasional Pendidikan, Standar Kompetensi dan Kompetensi Dasar, Jakarta, 2006.

[4] Prastowo. Andi, Panduan Kreatif Membuat Bahan Ajar Inovatif, Jogjakarta: DIVA Press, 2010.

[5] Hudoyo. H, Mengajar Belajar Matematika, Jakarta: P2LPTK, 1988.

[6] Novi. Trina, "Implementasi Pendekatan Contextual Teaching and Learning (CTL) Bernuansa Pendidikan Karakter untuk Meningkatkan Kemampuan Pemecahan Masalah Matematis Siswa MTsN", Jurnal Didaktik Matematika Volume 1 Nomor 1 April 2014.

[7] Nenden. Mutiara Sari, "Meningkatkan Kemampuan Pemecahan Masalah Matematis Dengan Metode Eksplorasi", Journal
Mathematics Education. Department of Mathematics Education, UMP Purwokerto, 2015.

[8] Ariandi. Yuli, "Analisis Kemampuan Pemecahan Masalah Berdasarkan Aktivitas Belajar Pada Model Pembelajaran PBL", Jurnal Seminar Nasional Matematika X Universitas Negeri Semarang, 2016.

[9] Rahayu. Putri, "Analisis Kesalahan Siswa SMP Dalam Menyelesaikan Soal SPLDV", Prosiding Seminar Nasional Etnomatnesia, ISBN: 978-602-6258-07-6, 2016.

[10] A.Bey dan Asriani, "Penerapan Pembelajaran Problem Solving untuk meningkatkan Aktivitas dan hasil belajar Matematika pada materi SPLDV", Jurnal Pendidikan Matematika Universitas Halu Oleo, Kendari Sulawesi Tenggara, 2013.

[11] Salmawaty, "Math Instructional Media Design Using Computer For Completion Of Two-Variables Linear Equation System By Elimination Method", Jurnal Natural, Vol.17, No. 1, 2017 Pissn 14118513 Eissn 2541-4062.

[12] Khotimah. R. P \& Masduki, "Improving Teaching Quality and Problem Solving Ability Through Contextual Teaching and Learning in Differential Equation: A Lesson Study Approach", Journal of Research and Advances in Mathematics Education ISSN: 2503-3697 Vol.1, No. 1, 1-13, January 2016.

[13] Gravemeijer. Koeno \& Doorman. Michiel, Context Problems in Mathematics Education: A Calculus Course As an Example. Educational Studies in Mathematics, 39: 111-129, 1999.

[14] Seifi. Mohammad, Haghverdi. Majid, Azizmohamadi, Fatemeh, "Recognition of Student's Difficulties in Solving Mathematical World Problems from the Viewpoints of Teachers", Journal of Basic and Applied Scientific Research, 2(3), 2923 -2928, 2012. 